\title{
DIGITAL LITERACY PROMINENCE AT DIGITAL ERA FROM THE PERSPECTIVE OF PHILOSOPHY OF VALUE (AXIOLOGY)
}

Sharfina Az-zahrin Hakim; sharfina.azzahrin.hakim-2020@fib.unair.ac.id' Anggie Ayu Isra Tristanty; anggie.ayu.isra-2020@ fib.unair.ac.id² Moses Glorino Rumambo Pandin; moses.glorino@fib.unair.ac.id ${ }^{3}$

English Language and Literature, Faculty of Humanity, Universitas Airlangga - Kampus B, Jl. Dharmawangsa Dalam, Airlangga, Kec. Gubeng, Kota SBY, Jawa Timur 60286 : (031) 5035676

\begin{abstract}
In this digital era, the urgency to learn digital literacy is very important. Digital literacy means having skills so that you can live, study, and work or thrive in society through digital platforms such as social media. Digital literacy has been used by various institutions, not only that, but everyone from students to workers should have this skill nowadays. The method used on this study is library analysis by using accumulating information, information, and statistics from numerous reliable resources associated with the subject. Google chrome helps search literature sources with the keywords "Digital Literacy", "Digital Age", "Philosophy", and "Axiology". There were 32 articles, seminars, journals, thesis, and so on. As well as one book that became used as a source of literature. Based at the studies we did, it suggests that Digital Literacy is certainly very vital on this digital era due to the fact it is simpler to apply and analyze. From the perspective of Axiology, it also shows that Digital literacy is very valuable especially that the world has been suffering from the pandemic. Other than that, digital literacy has risen in the past century. This article explores the importance of digital literacy through the perspective of philosophy values in the wave of the public eye. Here we will state an assertion from axiology perspective. In particular, this paper discusses the language and literature side in digital literacy along with some crucial roles about digital literacy. It is envisaged that the paper result may help people to understand more about literary and language importance in the digital era. The article also provides some recommendations based on literature study and previous research about digital literacy in the modern era.
\end{abstract}

Keywords : Digital Literacy, Digital Era, Philosophy, Axiology. 


\section{INTRODUCTION}

Nowadays, electronics are a crucial element. Humans frequently use electronics particularly in their everyday existence. Since the outbreak of Covid-19 all around the world, the number of readers and writers online has increased rapidly due to the application regulations of Work from Home. We can name this activity as digital literacy. Digital literacy itself comes from the phrases 'literacy' and 'digital'. Literacy method the potential to read and write while digital approach a gadget of receiving and sending statistics that indicates an electronic sign pastime. Therefore, digital literacy can be interpreted as an interest of reading and writing with the usage of a device carried out online or offline.

The Ministry of communication and information claims that digital literacy is a potential of someone in an effort to use a laptop and get admission to obtain accurate and ideal information. However, in digital literacy, a person must need the capability to recognize, analyze, and examine diverse forms of information. Those abilities can be beneficial to filter out the right information carried out online. Sincerely, with the effect of Covid-19 regulation, people begin to provide more attention, especially in the literature world. Literature is pieces of writing which might be valued as works of artwork, particularly novels, plays, and poems. Moreover, the value of literature has risen on the grounds that there are a variety of young writers who precede their artwork in recent times. Literature may be fashioned in multiple versions in a couple of genres. It could be fictional or nonfictional and the genres can be endless simply based on the author's creativity to mix and suit the outlines. In this digital era, it is not shocking news to find plenty of varieties of literacy art on the internet. Literacy roles in the digital era are predicted to be the key foundation for the future peculiarly in the educational section. Other than that, due to the outbreak of coronavirus, all learning is conducted online. It is informed that students with proper online literacy from modules possess facts better and get hold of greater grades than people who lacked in online literacy (Santoso, 2019). Furthermore, university students additionally acquire numerous benefits, mainly in online classes. They are able to use the web elegance functions better, specifically in answering the professor's questions in class. Other examples, they may gain several beneficial data carried out online to satisfy their task or extend their thoughts. 
Moreover philosophy and literacy are two matters that appeal to each other. Considering literacy desires philosophy to apprehend the oblique meaning. There are three philosophies we are able to use to interpret literature; epistemology, ontology, and axiology. However, we will discuss the affiliation between axiology and literacy. Axiology comes from the phrase Axios in Greek, it means price, and emblems which means idea. So, the definition of Axiology is the theory of cost that includes the implication of knowledge use. Axiology itself is an idea of value used to attach the usage of expertise acquired by way of people. It represents a comprehension which can categorize the statistics needed into beneficial advantages or the alternative manner round. Any philosophical studies that talk about axiology will create branches of philosophy which later emerge as one of the critical branches of knowledge; ethics and aesthetics. Essentially, we are able to inform that axiology is an examination to earn the motion values especially within the ethics and aesthetic component, and can interpret the hidden message in any literature. Other than that, axiology also concerns norm values to state the fact about existence which humans come across through the social surroundings.

Despite the fact that there is lots of data about the correlation among philosophy and literature, we genuinely could not discover the prominence of digital literature within the perspective of axiology. Therefore, the intention of this research is to locate the comparability of philosophy, specifically axiology toward digital literacy. We hope our studies can provide a perception of how literature may be in the angle of Axiology.

The purpose of this research is to identify a concept, review, test, and prove the truth of existing knowledge based on the title of this article or the fact that digital literacy has had such a huge impact on this world and how the public views this new literary form. We will also make predictions about what effect this knowledge will have in the future. We will also try to find solutions to possible situations in this type of knowledge, which are described in the following paragraphs. The benefits of this research can also be seen as a form of developing existing knowledge, namely digital literacy is a new way of how people channel their knowledge and skills through digital platforms for work and way of life.

There are several problems we want to discuss namely; (1) What is the role of language and literature in the digital era? (2) How can we identify the axiology perspective through digital literacy? (3) Why is digital literacy considered to be a crucial role in 
supporting the future? (4) How does the public view this digital literacy? Do they think it advantages them or disadvantages them?

\section{METHODS}

In making this paper, a qualitative approach is used by emphasizing the aspect of indepth understanding of a problem. The basic source of this paper is the results of research that are in accordance with the topic. In the implementation of scientific papers, we have taken several steps; including collecting the data needed in the research, grouping the data based on the classification and description to fit the theme of the paper, and have designed what is needed to continue the work process.

The data evaluation technique used is a qualitative technique, similar to the research approach technique that specializes in conceptual and non-numeric matters. This research was conducted using Microsoft Office Word software, Google Chrome Web Search, and other operating systems on the computer. The publication target will be in accordance with the deadline that has been given, or namely at the end of the month of December. The target audience for this paper is the general public.

Qualitative research evaluation priority is within the documentation segment, which involves documents such as; journals, books, and pre-organized information files from the latest studies. The technique uses a system to acquire several existing portions of journals and books databases on the collection of browse historical information details. Further, we additionally use focus group discussion data analysis. The approach means in a set, we try an attempt to find the meaning of our topic issues in a discussion to avoid being misunderstood with the aid of a researcher. The other intention is also to reach the same perspective in solving the issues discussed inside the research. Contrarily, in this paper we behave in numerous ranges to fulfill our studies' effects. These ranges are explained within a diagram of the research procedure. 


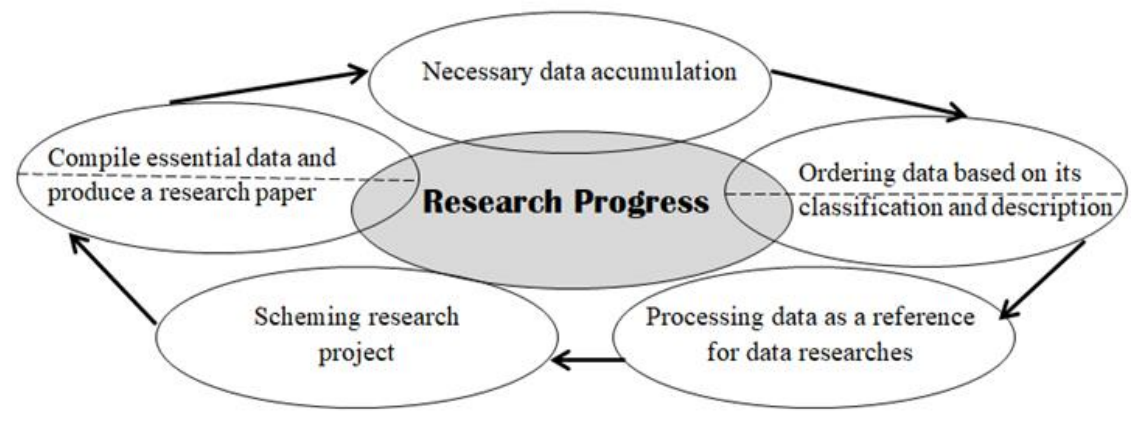

Table 1. Diagram process of this research

\section{RESULTS :}

Literature manner is a character talent to apprehend digital content material (Dewi et al., 2021). Formerly, literacy is interpreted as the ability to use language in unique ways to read, write, listen, talk, express, and reflect crucial ideas. It is also known that cyber literature is about the outlook of human daily lifestyles from the angle of the writer. they have the power to describe "how the world is" from their point of view. Aside from the opposite position defined earlier, literature might also show the lifestyle sides of the author's provenance or supply the reader a perception of an idea from the decision of the art. From the artwork, the identification or civilization of a state may be recognized by other human beings. Therefore, art can be a media for human beings to improve their view about culture. As a result, literature is considered to be a medium for cultural creativity filled with complicated communications through words. It includes one subculture with every other cultural society in a unique communique (Dewi, 2020).

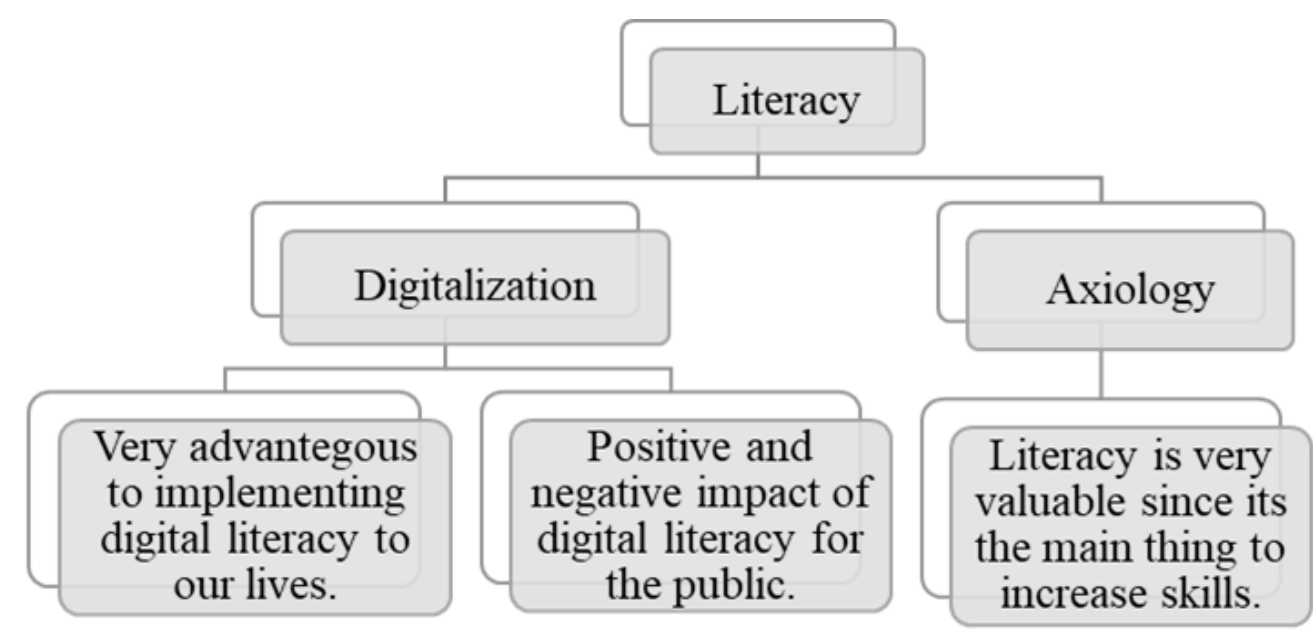

Table 2. Result of of the data that found from data analysis based on articles and journals 
Subsequent development has proven literacy is associated with the state of affairs and alertness of human lifestyles according to the notion of the author. Table 2 shows the advantages of digital literacy implementation primarily based on the research from Sumiati and Wijonarko. The table illustrates the digital literacy benefits in four figures. Therefore, literature additionally performs a big role in social life to extend the fine of an individual.

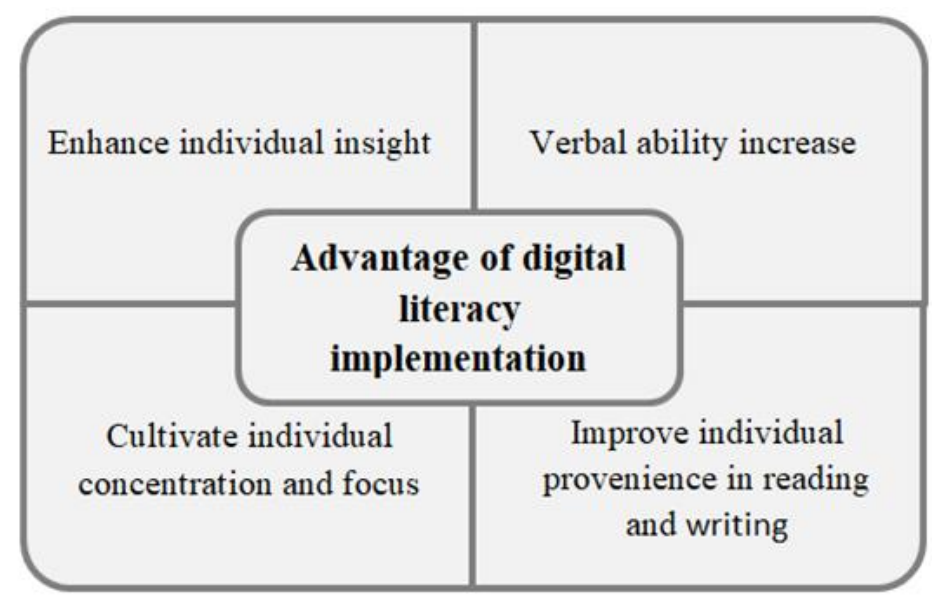

Table 3. Advantage of digital literacy implementation

In addition to the table, e-literacy also can prevent someone from being stimulated by radicalism. As all of us understand, today everything is provided online. Inside the online world, there is no prior law, in consequence, there is lots of hoax news that may trigger radicalism in society. Radicalism comes from exceptional opinions and protests toward an issue. The internet is one of the media that spreads radicalism easily. Thus, literature right here may be an instrument to prevent the propaganda of radicalism online. In reality, the authorities already set up rules to extend 73 tremendous pieces of digital literature in 442 locations (Aulya et al., 2020). Other than that, e-literacy also plays a massive role in growing ICT skills among college students. There are three capabilities to elevate the facts of virtual literacy namely (Herlina et al., 2020):

1. Media literacy, this ability calls for the capability to select and elevate facts as a verbal exchange media.

2. Information literacy, this ability calls for the potential to get admission to affective records performed online, afterward, the information provided needs to be evaluated severely using correct strategies. 
3. Communication Technology literacy, this ability calls for the skill to analyze the media records and invent an appropriate manner to convey the data.

The succession of elaborating facts in virtual literacy can trigger the mindsets of a person. Apart from that, it may additionally increase problem-solving abilities. Therefore, literacy within the digital era holds the key to create a successful generation for the future (Sujana \& Rachmatin, 2019).

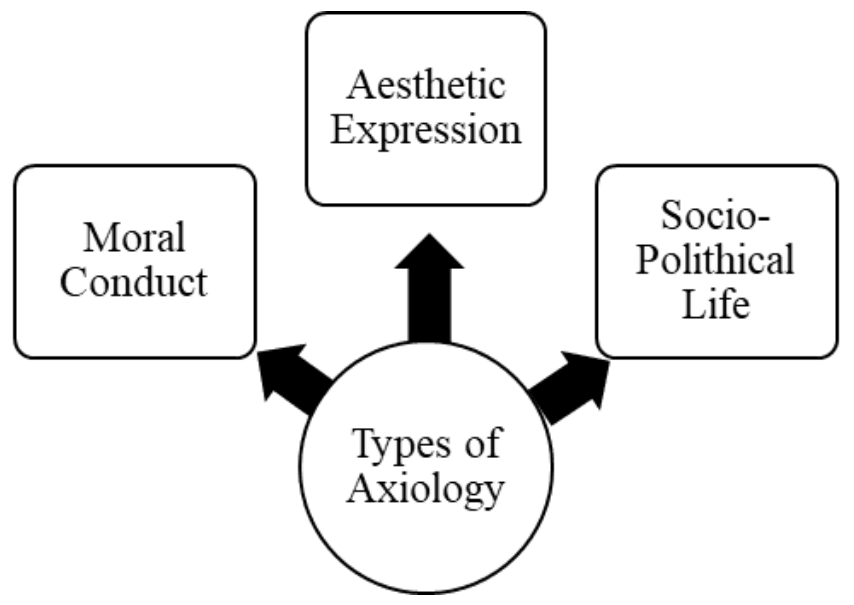

Picture 1. Types of Axiology

Axiology is a part of philosophy which questions how humans use their expertise. In axiology, it is more about the values which include reality, quality, beauty, and faith (Nurhidayah \& Setiawan, 2019). This branch of philosophy studies the usage of knowledge then relates it to the standards of values. Axiology is split into three; (1) moral conduct, it creates the values concerning discipline, specifically "science of ethics" or ethical values, (2) Aesthetics expression, it creates the splendor concept or aesthetic values, (3) Socio-Political life, this department creates the values of society and politics (Syafitri et al., 2021). We are able to include that axiology research the highest essence of moral and aesthetic values. Related to literature, axiology gives numerous perspectives to help and examine literature (Sastra, 2020).

The example of axiology views application is inside the Indonesian Language Books edition 2017 by the Ministry of education and culture. It is an easy example from numerous types of literature. Indonesian language books are commonly full of literary and language material. In literary material, the axiology angle plays a big role. genuinely in it, there might be poetry cloth and text assessment. The text assessment might be an artwork and discussed 
in the scope of value. The scope of value or axiology can describe the middle abilities and primary abilities as one (Sastra, 2020). As a result, it could be recognized that the e-book offers benefits in terms of learning and social aspects. In learning, it conveys values meanwhile in social perspective, it increases the students' sensitivity to the values of social life which includes; religion, responsibility, confidence, essential, way of life, critical thoughts, pleasant manners, and politeness (Dwi, 2021).

Digital literacy has existed from decades ago, and when it viewed from the perspective of society from ten years ago, what we are currently experiencing is the result of the role of digital literacy in supporting the future. SO, why is digital literacy called to be the door to the future? It is because digital literacy is the most crucial aspect of technology that can support the future. Digital literacy encourages people to be creative and innovative, and it can support job creation. Digital literacy can also augment what traditional literacy had been done before.

The role of digital literacy that will be most prominent in the future comes from the education sector. Nowadays, there are lots of start-ups or learning applications that support learning activities easily and even from home. With this, the Government itself also intervenes by collaborating with various platforms or applications to provide free learning facilities. (Supriadi, 2020). Free learning applications can make students throughout Indonesia and even the world able to access learning materials and take their classes anywhere and anytime as long as there are internet facilities nearby.

In the future, digital literacy can also help people to be more productive and do their work or business without limits through various e-commerce platforms. We will never know when this covid-19 pandemic will really end or if it could end, therefore this is where digital literacy plays a very important role, because maybe we will be constantly forced to work not on the field. Digital literacy can help business people to manage their business from anywhere and anytime without having to go to the field because there will be unlimited communication facilities, digital literacy can also help business owners to prevent threats such as cyber-crime by managing their business page, for all we know is quite easy to secure our business page form the e-commerce platform.

Digital literature is very dependent on social media because social media is the main influence why digital literacy is so prevalent today, especially during the pandemic. Digital 
literacy itself always increases from year to year, which of course continues to increase until now. Despite the large number of digital literacy users, it does not mean we will always get a positive impact from this advanced technology. Many people of course view that this technology has more positive sides than negatives. Positive examples of digital literacy are; make it easier to get the information we need, enhancing the satisfactory of human sources through the development and use of information and verbal exchange technology, improving the fine of our schooling machine, and lots more. (Wahyuni, 2020). Some people may not feel the negative impact of digital literacy but slowly this is unraveling in front of them without them realizing it. The negative impact itself is that, because digital literacy opens people's eyes to the wider world, it is undeniable that people's thinking will be easier to become more universal. This universality is actually one of the negative impacts that can be caused by digital literacy. Even before the advent of digital literacy, society itself was very diverse in terms of social status. The diversity of social relations can lead to disharmony, conflict, between ethnic groups and internal conflicts. (Safri, A. Syukri A. Badarussyamsi, 2021).

\section{DISCUSSION :}

These days, digital literature is vital for human beings including students. From the axiology perspective, literature holds an exquisite key for the future of human beings. explained before, axiology here offers a perception of values conducted in literature. The values involve ethical movement, beauty expression, and socio-political existence. Furthermore, in literature, they will exude ideas, emotion, beauty, and unique look. Hereby with the axiology concept, literature plays a big role in the digital era to form the characteristics of the readers. Aside from that, in addition, they increase the social sensitivities of readers.

Literacy itself is an ability in aspects of socializing that are not only reading, writing, and speaking, but also a real skill regardless of the context of who and for whom. In this alldigital era, literacy plays a very important role because of the increasing number of new literacies that continue to emerge to find technology. One of the new literacies that is very important for digital literacy is information literacy which is a paradigm and reference in 
socializing and living life. This literacy is also the most accessible literacy because there are a lot of resources that we can find if we want to get to know more about this kind of literacy.

Literature conveys thoughts and creativity from human beings within the shape of a script or manuscript. In literature, the author is responsible for the general message. Here axiology may also take a part to pick out the message from the author. The message can be hidden or written in the story. In reality, there are fiction and nonfiction styles of literacy. The fiction aspects offer imaginary situations while the non-fictional sides provide real-life situation scenarios. Those reflections of situations might also create a symbol and considerable cause through the medium of language. The result may be mentioned inside the axiology perspective. Axiology perspectives approach analysing and decoding the values in any literature. The values right here exclude moral action, beauty expression, and sociopolitical life. In a word, its studies deliver a description of goodwill and proper behavior (Anugrah et al., 2019). Apart from that, exploring the values in literature can be the form of numerous reports which only maybe felt after identifying the ideas, feelings, splendor, and forte in literature.

In the future, digital literacy can also help people to be more productive and do their work or business without limits through various e-commerce platforms. We will never know when this covid-19 pandemic will really end or if it could end, therefore this is where digital literacy plays a very important role, because maybe we will be constantly forced to work not on the field. Digital literacy can help business people to manage their business from anywhere and anytime without having to go to the field because there will be unlimited communication facilities, digital literacy can also help business owners to prevent threats such as cyber crime by managing their business page, for all we know is quite easy to secure our business page form the e-commerce platform. 


\section{CONCLUSION}

Digital literacy is an important aspect now and in the future. Digital literacy itself has played a significant role in the past few decades. In fact, if we want to live and survive in society, we are required to have skills that support digital literacy such as the ability to control technology. Before the digital era like now, literacy itself has played an important role not only for youth but for all people of all ages. Not only from the aspect of education, but literacy has provided various benefits for its readers. Seen from the perspective of axiology which looks at the value of a thing. So from some of the discussions that have been given, we can conclude that in this digital era, literacy is one of the keys to success for future generations. This is because based on an axiological review, apart from being able to support one's critical thinking skills, digital literacy can increase one's social effectiveness. This effectiveness is related to the moral values contained in one example, giving an idea of how humans should act with others. Therefore, digital literacy skills in this telecommunication era can provide benefits both from a scientific perspective to a social aspect.

\section{REFERENCES}

Isbah, et al. (2021). Perspektif Ilmu Ilmu Sosial di Era Digital. Edisi, Gadjah Mada University Press. Sleman, D.I. Yogyakarta.

Mushlihah, N. Q. A. (2020). Proses Konstruksi Indentitas Pembaca Karya Sastra Jawa di Kalangan Anak Muda Urban. Palimpsest: Jurnal Ilmu Informasi dan Perpustakaan, 11(2): 106-124.

Pamungkas, E. B., \& Mandarani, V. (2021). Kemanusiaan dan Kearifan Sejarah dalam Pemikiran Pramoedya Ananta Toer (Kajian Historiografi). KAMBOTI: Jurnal Sosial dan Humaniora, 1(2): 166-172.

Anugrah, E. R., Rahmat, R., Arlita, A., \& Sofyan, A. (2019). Gambaran Kesuksesan dan Kebahagiaan. Journal of the Japan Welding Society, 88(5): 366-374.

Aufadina, K., \& Irfansyah, M. (2021). MODERNISASI, LAYAR MONITOR, DAN PERUBAHAN BUDAYA. Lakon: Jurnal Kajian Sastra dan Budaya, 10(1): 1-10. 
Zulfa, A. N. (2021). TEORI EKOKRITIK SASTRA: KAJIAN TERHADAP KEMUNCULAN PENDEKATAN EKOLOGI SASTRA YANG DIPELOPORI OLEH CHERYLL GLOTFELTY. Lakon: Jurnal Kajian Sastra dan Budaya, 10(1): $50-63$.

Wahyuddin, Z. (2020). REFLEKSI KETERHUBUNGAN FILSAFAT ILMU PENGETAHUAN DAN SASTRA. mezurashii, 2(1): 49-53.

Wanti, M. A. (2020). KURASI DIGITAL SASTRA SIBER: PERSPEKTIF SASTRA KONVENSIONAL. Jurnal Kearsipan, 15(1): 45-62.

Nurhidayah, S., \& Setiawan, R. (2019). Lanskap Siber Sastra: Postmodernisme, Sastra Populer, dan Interaktivitas. Poetika: Jurnal Ilmu Sastra, 7(2): 136-147.

Rodli, R., Nugraheni, L., \& Ediyono, S. (2019). PEMIKIRAN FILSAFAT DALAM NOVEL “GERAK-GERIK” KARYA AH. J. KHUZAENI. PENTAS: Pendidikan Bahasa dan Sastra Indonesia, 5(1): 15-23.

Wahyuni, D. (2020). Meningkatkan Pembelajaran Sastra Melalui Perkembangan Era Digital. Jurnal Edukasi Kultura: Jurnal Bahasa, Sastra dan Budaya, 7(1): 2-8.

Safri, A. (2021). Philosophy Of Science Relations In Scientific Research And Social Life. Qolamuna: Jurnal Studi Islam, 7(1): 37-50.

Irhandayaningsih, A. (2020). Pengukuran literasi digital pada peserta pembelajaran daring di masa pandemi covid-19. Anuva: Jurnal Kajian Budaya, Perpustakaan, dan Informasi, 4(2), 231-240.

Santoso, I. A. P., Anwar, S., \& Waluyo, S. D. (2020). Peran siberkreasi dalam meningkatkan kemampuan literasi digital untuk mencegah aksi radikalisme. Peperangan Asimetris, 6(1): 43-64.

Shepherd, T., \& Henderson, M. J. (2019). Digital Literacy in Digital Strategy. Canadian Journal of Communication, 44(2): 51-56.

Syafitri, E., Armanto, D., \& Rahmadani, E. (2021). AKSIOLOGI KEMAMPUAN BERPIKIR KRITIS (Kajian Tentang Manfaat dari Kemampuan Berpikir Kritis). JOURNAL OF SCIENCE AND SOCIAL RESEARCH, 4(3): 320-325. 
Sujana, A., \& Rachmatin, D. (2019). Literasi digital abad 21 bagi mahasiswa PGSD: apa, mengapa, dan bagaimana. In Current Research in Education: Conference Series Journal, 1(1): 1- 6 .

Rosnawati, R., Syukri, A. S. A., Badarussyamsi, B., \& Rizki, A. F. R. A. F. (2021). Aksiologi Ilmu Pengetahuan dan Manfaatnya bagi Manusia. Jurnal Filsafat Indonesia, 4(2): 186-194.

Rahmasari, N. V. D, Zuchdi D. (2021). Tinjauan Ontologi, Epistemologi, dan Aksiologi Materi Sastra dalam Buku Teks Bahasa Indonesia Kelas VII. Jurnal Filsafat Indonesia, 4(1): 111-116.

Dewi, D. A., Hamid, S. I., Annisa, F., Oktafianti, M., \& Genika, P. R. (2021). Menumbuhkan Karakter Siswa melalui Pemanfaatan Literasi Digital. Jurnal Basicedu, 5(6): 52495257.

Blokh, M. Y., Asratyan, Z. D., \& Asratyan, N. M. (2019). Topic of the Imaginative Text and Its Philosophical and Linguistic Presentation. Journal of History Culture and Art Research, 8(2): 128-135.

Falloon, G. (2020). From digital literacy to digital competence: the teacher digital competency (TDC) framework. Educational Technology Research and Development, 68(5): 2449-2472.

Nichols, T. P., \& Stornaiuolo, A. (2019). Assembling "digital literacies": Contingent pasts, possible futures. Media and Communication, 7(2): 14.

Harisanty, D., Srirahayu, D. P., Anna, N. E. V., Mannan, E. F., Anugrah, E. P., \& Dina, N. Z. (2021). Digital Literacy for Covid 19 Information in Indonesian Society. Library Philosophy and Practice, 1-14.

Emawati. (2020). Disrupsi Pembelajaran Bahasa dan Sastra Indonesia pada Era Digital. Prosiding Seminar Nasional Pendidikan Program Pascasarjana Universitas PGRI Palembang. 10 Januari 2020, Palembang, Indonesia. pp 1069-1077. 
Dasuki M. R. (2020) Tiga Aspek Utama Dalam Kajian Filsafat Ilmu; Ontologi, Epistemologi, dan Aksiologi. Seminar Nasional Bahasa dan Sastra Indonesia Unpam. 2019, Pamulang, Indonesia. pp 81- 85.

Amelia, A. and Rudiansyah. (2021). Digitalisasi dan Pembelajaran Bahasa di Era Digital. Seminar Nasional Pembelajaran Bahasa dan Sastra. 12 Juni 2021, Malang, Indonesia. pp 96-104.

Novianty, D.U. and Pandin, M.G.R. (2021) Analyzing How Millennial Generation Implement Pancasila Value in Modern Era. Thesis. Universitas Airlangga, Surabaya.

Rojuli, S. K., and Pandin, M. G. R. (2021). Paradigm of Historical Science: Dealing with the Modern Juggernaut through across Time in Education and Government. Thesis. Universitas Airlangga, Surabaya.

Nur, N. I. and Pandin, M. G. R. (2021). The Transformation of Education in Indonesia from the Colonial Era to the Digital Era is Reviewed from a Historical Perspective. Thesis. Universitas Airlangga, Surabaya.

Azzahra, N. F. and Amanta, F. (2021). Promoting Digital Literacy Skill for Students through Improved School Curriculum. URL : https://www.cips-indonesia.org/post/policybrief-promoting-digital-literacy-skill-for-students-through-improved-schoolcurriculum Accessed on 16 December 2021.

Supriadi, A. (2020) Gerakan Literasi Digital Solusi Hadapi Krisis Pendidikan dan Ekonomi di Masa Pandemi Covid-19. URL : https://www.untan.ac.id/gerakan-literasi-digitalsolusi-hadapi-krisis-pendidikan-dan-ekonomi-di-masa-pandemi-covid-19/ Accessed on 17 December 2021.

Sholikhah, N. (2021) Diskusi Cyber Demokrasi, Khairul sebut Ruang Digital bisa Menjadi Ajal bagi Demokrasi Indonesia. URL : http://news.unair.ac.id/2021/11/22/diskusicyber-demokrasi-khairul-sebut-ruang-digital-bisa-menjadi-ajal-bagi-demokrasiindonesia/ Accessed on 19 December 2021. 